\title{
Analisis Soal Computer Based Test untuk Tes Potensi Akademik dan Biologi Manusia
}

\author{
http://dx.doi.org/10.28932/jutisi.v7i3.4027
}

Riwayat Artikel

Received: 30 September 2021 | Final Revision: 10 Desember 2021 | Accepted: 12 Desember 2021

\author{
Adelia $^{\bigotimes \# 1}$, Tiur Gantini ${ }^{* 2}$, Victor Kurniawan ${ }^{\# 3}$ \\ \#* Program Studi Sistem Informasi, Fakultas Teknologi Informasi, Universitas Kristen Maranatha \\ Jl. Surya Sumantri No. 65 Bandung \\ ${ }^{1}$ adeliadit.maranatha.edu \\ ${ }^{2}$ tiur.gantinieit.maranatha.edu \\ ${ }^{3}$ victvict.1196@gmail.com
}

\begin{abstract}
Education providers, one of which is a private university in Bandung, conducts entrance exams for student participants through a computer-based test system. In the entrance examination, which is carried out is a test of academic potential and human biology. Every question that belongs to both the TPA and human biology questions is stored in the university's computer-based test system. The saved questions can be used at any time, during the entrance examination period. The stored questions need to be analyzed and reviewed, with the aim that the questions can be used properly and can maintain the quality of the questions given to each examinee. In this study, an analysis of the level of difficulty and effectiveness of the distractor will be carried out. This analysis is carried out using data from 2018 to 2020 stored in the system.
\end{abstract}

Keywords - computer based test; distractor; level of difficulty.

\section{PENDAhUluan}

Computer based test merupakan salah satu sistem ujian yang digunakan oleh sebuah universitas swasta di Bandung untuk melakukan ujian saringan masuk peserta calon mahasiswa. Ujian saringan masuk yang diujikan adalah tes potensi akademik yang selanjutnya akan disingkat menjadi TPA bagi seluruh peserta dan tes khusus yang diikuti oleh peserta yang mengambil fakultas kedokteran yaitu tes biologi manusia. Seluruh peserta mengerjakan semua soal ujian saringan masuk pada waktu yang telah ditentukan dan dilakukan secara online. Dengan menggunakan sistem computer based test, peserta dapat melakukan tes pada tempat yang berbeda, dengan menggunakan jaringan internet atau intranet sesuatu organisasi [1].

Penggunaan sistem computer based test, memiliki banyak manfaat diantaranya adalah dapat menghemat biaya percetakan dan pengiriman, peningkatan keamanan data ujian dapat dilakukan dan data ujian dapat dikumpulkan secara otomatis serta mempermudah proses penilaian [2]. Manfaat penggunaan computer based test lainnya adalah adanya efektivitas waktu yang digunakan mulai dari membuat soal sampai dengan tahap penilaian yang dilakukan [3]. Penelitian lain juga menjelaskan penggunaan sistem computer based test dapat digunakan untuk membantu proses ujian dan evaluasi hasil pembelajaran yang dilakukan oleh pihak sekolah [4].

Manfaat yang dimiliki dari sistem computer based test, dimanfaatkan oleh pihak universitas. Pihak universitas telah menyusun dan menyimpan Soal TPA dan soal biologi manusia pada sistem computer based test. Soal TPA dan biologi manusia tidak dicetak dan disebarkan secara digital sehingga membuat pihak universitas lebih hemat biaya dan keamanan data soal dan hasil pengisian soal terjaga. Kumpulan soal tersimpan dalam sistem computer based test yang dikelompokan dalam blok soal dan dapat dipilih pada saat masa penyelenggara ujian saringan masuk, baik untuk soal TPA maupun biologi manusia sesuai konfigurasi yang telah diatur pada sistem. Blok soal dapat dipilih sesuai dengan kebutuhan dan soal akan dipilih secara acak dari kumpulan soal sesuai blok yang yang ada. Pemilihan soal secara acak dari kumpulan soal dilakukan untuk memastikan setiap peserta mendapatkan soal yang berbeda dengan peserta lain. Peserta yang melakukan pengulangan tes maka soal yang berbeda dari tes sebelumnya. Computer based test dapat menampilkan soal secara acak sehingga soal yang ditampilkan pada setiap peserta akan berbeda, serta memudahkan dalam proses penilaian hasil ujian [5]. Jawaban soal dari setiap siswa tersimpan otomatis dan dapat langsung diolah nilainya dikarenakan dalam sistem computer 
based test, pihak universitas telah menyimpan soal beserta dengan jawabannya. Soal dan jawaban yang tersimpan dalam sistem menjadi bank soal yang dapat dipilih ketika ujian saringan masuk dilaksanakan, berdasarkan blok yang ada.

Soal TPA dan tes biologi manusia perlu dianalisis agar soal dapat terus diperbaiki dan ditingkatkan kualitasnya. Analisis soal perlu dilakukan untuk mengetahui kualitas dari butir soal. Soal yang berkualitas terdiri dari butir soal yang berkualitas juga tentunya [6]. Analisis soal dapat dilakukan dengan melakukan analisis dalam hal validitas, reliabilitas, tingkat kesukaran, daya pembeda dan efektivitas distraktor [6] [7] [8]. Soal TPA dan biologi manusia yang digunakan sejak tahun 2017 dengan menggunakan sistem computer based test, telah dilakukan analisis dalam hal validitas, reliabilitas, tingkat kesukaran, dan daya pembeda dengan menggunakan data dari tahun 2017 sampai dengan 2019 [9]. Analisis yang dilakukan saat ini merupakan pengembangan dari penelitian sebelumnya dan menggunakan data yang berbeda, yaitu data tahun 2018 sampai dengan 2020 serta melakukan analisis tingkat kesukaran soal dan efektivitas soal pengecoh atau efektivitas distraktor.

Cara untuk mengukur kesukaran soal yang diberikan pada sekelompok peserta ujian, dapat dilakukan dengan melakukan analisis tingkat kesukaran [10]. Analisis efektivitas distraktor digunakan pada soal pilihan ganda yang memiliki alternatif jawaban lebih dari satu [11]. Distraktor adalah alternatif pilihan jawaban lain yang diberikan dalam soal pilihan ganda dan bukan merupakan kunci jawaban [11] [12]. Untuk mengetahui seberapa efektif distribusi kunci jawaban dan jawaban pengecoh atau distraktor pada sebuah soal, analisis distraktor perlu dilakukan [12]. Analisis tingkat kesukaran dan efektivitas distraktor juga merupakan salah satu cara untuk mengukur prestasi belajar [7]. Analisis tingkat kesukaran dan distraktor yang dilakukan pada penelitian ini dilakukan untuk mengetahui kualitas dari setiap butir soal, agar butir soal dapat dipertahankan atau diperbaiki. Selain itu penelitian ini dapat digunakan untuk mengetahui prestasi belajar peserta tes dari tingkat kebenaran jawaban benar dari setiap butir soal.

\section{METODE}

Pada penelitian analisis soal computer based test untuk soal TPA dan Biologi, analisis dilakukan melakukan empat tahapan penelitian, yang ditunjukkan pada Gambar 1.

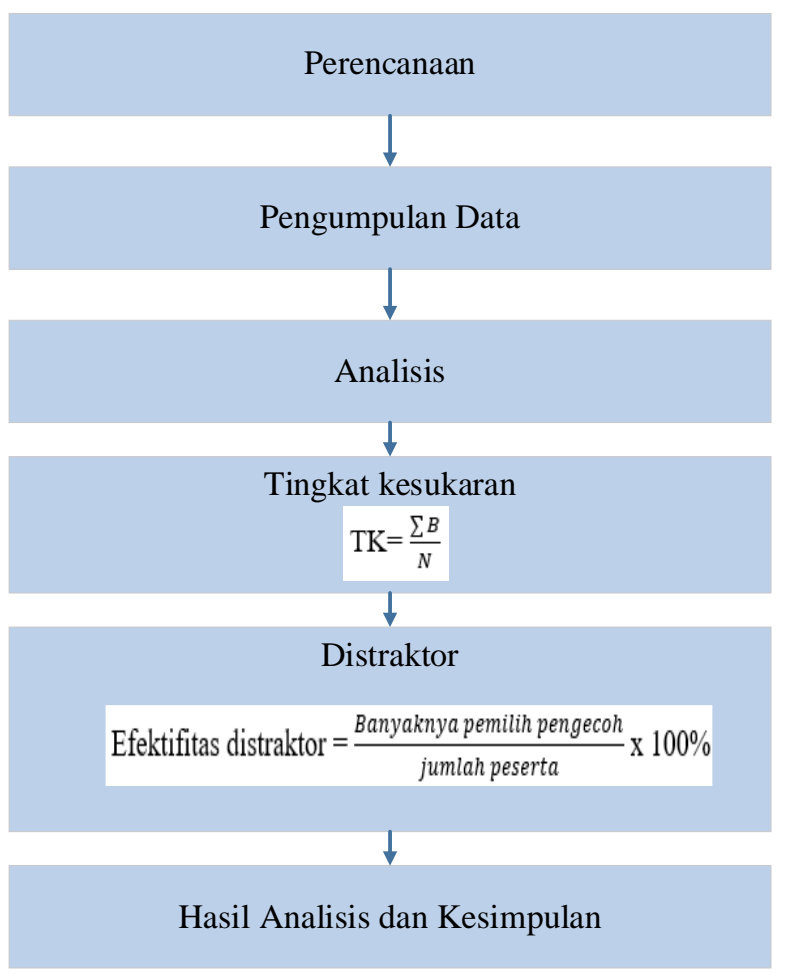

Gambar 1 Tahapan Penelitian 
Tahapan penelitian yang dilakukan ditunjukkan pada Gambar 1, dan memiliki penjelasan lebih rinci, untuk setiap prosesnya, sebagai berikut;

\section{A. Perencanaan}

Pada tahap ini, dilakukan perencanaan penelitian, yaitu analisis yang akan dilakukan dan menentukan data yang digunakan dalam penelitian. Analisis yang dilakukan untuk menganalisis data soal yaitu analisis tingkat kesukaran dan distraktor.

B. Pengumpulan Data

Data yang digunakan adalah data soal periode 2018 sampai dengan 2020. Soal yang didapatkan lengkap berserta jawaban diambil dari sistem computer based test yang digunakan oleh pihak universitas. Soal TPA yang dianalisis pada penelitian adalah sebanyak 893 soal dan untuk soal biologi dari total soal yang terdapat dalam sistem computer based test sebanyak 1016 soal, yang digunakan dalam penelitian ini sebanyak 123 soal. Penggunaan 123 soal biologi, dilakukan dengan melihat jumlah soal yang paling sering digunakan pada masa periode data penelitian. Pada soal TPA setiap tahun rata-rata menggunakan lima blok soal yang berbeda, sedangkan pada soal biologi setiap tahun menggunakan rata-rata dua blok soal yang berbeda.

C. Analisis

Setelah data soal didapatkan dilakukan analisis terhadap butir soal dengan menggunakan analisis tingkat kesukaran dan distraktor. Analisis tingkat kesukaran menggunakan metode komparasi tunggal dengan rumus [13]:

$\mathrm{TK}=\frac{\sum B}{N}$

Keterangan:

\section{TK= Tingkat Kesukaran}

$\sum_{\mathrm{B}}=$ Jumlah siswa yang menjawab benar

$\mathrm{N}=$ Jumlah siswa.

Kriteria tingkat kesukaran hasil dari perhitungan metode komparasi tunggal, sebagai berikut; [13]

1. Jika jumlah persentase keberhasilan berada pada nilai 0-29,9\% maka soal masuk pada kategori sulit

2. Jika jumlah persentase keberhasilan berada pada nilai 30-70,9\% maka soal masuk pada kategori sedang

3. Jika jumlah persentase keberhasilan berada pada nilai diatas $71 \%$ maka soal masuk pada kategori mudah

Analisis distraktor pada soal TPA dan biologi manusia, menggunakan rumus [14]:

Efektivitas distraktor $=\frac{\text { Banyaknya pemilih pengecoh }}{\text { jumlah peserta }} \times 100 \%$

Pengelompokan efektivitas distraktor, sebagai berikut [15]

1. Jika distraktor dipilih sekurang-kurangnya 5\%, maka distraktor tersebut berfungsi dengan baik

2. Jika distraktor dipilih dari $0 \%$ sampai $5 \%$, maka distraktor tersebut perlu dilakukan revisi.

D. Hasil Analisis dan simpulan

Hasil dari analisis dari tingkat kesukaran dan analisis distraktor ditampilkan dalam bentuk tabel dan grafik.

\section{HASIL DAN PEMBAHASAN}

Pada bagian ini dijelaskan mengenai proses analisis tingkat kesukaran dan analisis distraktor. Analisis soal TPA dan soal biologi manusia akan dijelaskan juga pada bagian ini.

\section{A. Proses Pengolahan Soal Computer Based Test}

Proses pengolahan soal computer based test yang dilakukan dalam penelitian analisis tingkat kesukaran dan distraktor, ditunjukkan pada Gambar 2. 


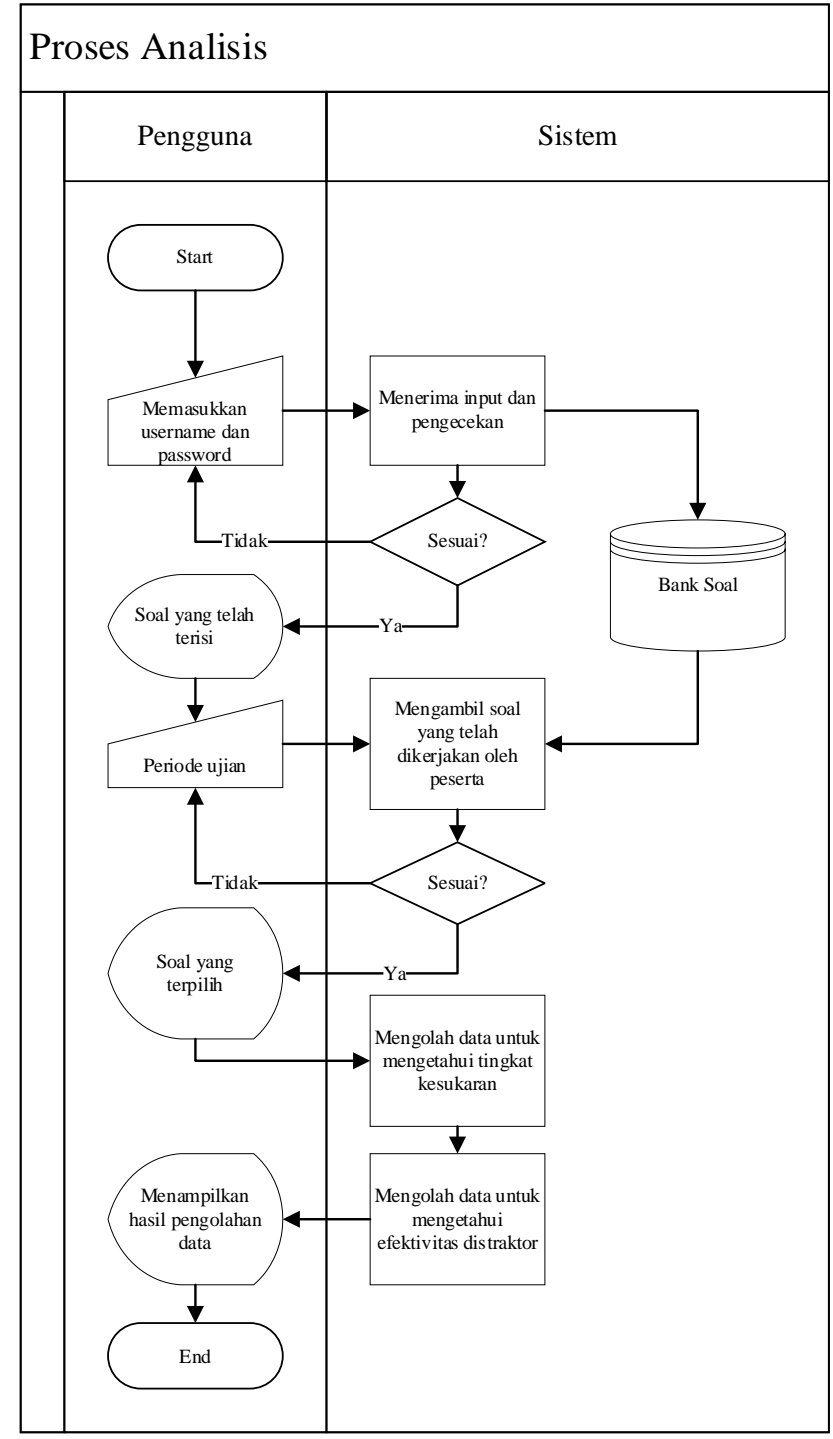

Gambar 2 Proses Pengolahan Soal

Pengguna memasukkan password dan username, dilakukan pengecekan dalam sistem. Jika password dan username salah maka pengguna dapat memasukkan kembali password dan username. Jika benar maka pengguna dapat melihat soal yang telah dikerjakan peserta. Pengguna dapat memilih periode ujian, lalu sistem akan mengambil soal yang telah dikerjakan oleh peserta jika sesuai, maka soal akan tampil, jika tidak maka dapat memasukkan periode kembali. Soal yang terpilih diolah untuk menghitung tingkat kesukaran dan mengetahui efektivitas distraktor. Hasil perhitungan ditampilkan pada layar.

Algoritma yang digunakan untuk menghitung tingkat kesukaran untuk setiap butir soal, adalah sebagai berikut;

- Input: data peserta ujian, jawaban setiap soal dari peserta ujian, jawaban benar tiap soal

- Process:

i. Bandingkan jawaban setiap soal dari peserta ujian dengan jawaban benar tiap soal, kemudian jumlahkan peserta ujian yang menjawab benar

ii. Hitung tingkat kesukaran soal dengan rumus jumlah siswa yang menjawab benar dibagi dengan jumlah siswa yang mengikuti ujian

iii. Lalu bandingkan perhitungan tingkat kesukaran, untuk menghasilkan kategori soal. jika hasil perhitungan berada pada nilai 0-0,29 maka soal masuk pada kategori sulit. Jika hasil perhitungan berada pada nilai 0,30 0,70 maka soal masuk pada kategori sedang. Jika hasil perhitungan berada pada nilai diatas 0,71 maka soal masuk pada kategori mudah 
- Output : Tingkat kesukaran soal dan kategori tingkat kesukaran menjadi output perhitungan

Algoritma yang digunakan untuk menghitung tingkat efektivitas distraktor untuk setiap butir soal, adalah sebagai berikut;

Input: data peserta ujian , jawaban setiap soal dari peserta ujian, jawaban benar tiap soal

- Process

i. Hitung efektivitas distraktor untuk setiap butir jawaban (untuk jawaban A,B,C,D,E)

- Jawaban A:

- Banyak pemilih Jawaban A = jumlahkan peserta yang memilih A tiap soal

- $\mathrm{N}=$ jumlahkan semua peserta

- Jawaban A = Banyak pemilih jawaban A / N * $100 \%$

- Lalu bandingkan jawaban A dengan jawaban benar, maka jawaban diberikan tanda benar

- Ulangi perhitungan dan perbandingan jawaban untuk jawaban B,C,D dan E

ii. Lalu bandingkan semua hasil jawaban, jika hasil lebih dari 5\% maka jawaban tersebut memiliki tingkat efektivitas distraktor yang baik, maka masuk pada kategori soal diterima. Jika hasil antara 0\% sampai dengan 5\% maka jawaban tersebut memiliki tingkat efektivitas distraktor yang kurang baik, maka masuk pada kategori soal perlu diperbaiki

- $\quad$ Output = jawaban A, jawaban B, jawaban C, jawaban D, jawaban E, kategori soal

\section{B. Analisis Soal TPA}

Pada bagian ini dijelaskan mengenai hasil analisis kesukaran dan analisis distraktor pada soal TPA pada Universitas swasta di Bandung. Data yang digunakan untuk 893 data soal TPA yang digunakan pada periode 2018 sampai dengan 2020 ujian saringan masuk universitas, dengan rata-rata penggunaan lima blok soal yang berbeda setiap tahunnya. Perhitungan dan analisis tingkat kesukaran soal dan distraktor dilakukan untuk keseluruhan data yang didapatkan, namun pada paper ini, ditampilkan sebanyak 35 data sampel atau data soal. Hasil perhitungan dan analisis tingkat kesukaran pada soal TPA ditunjukkan pada Tabel 1 dan perhitungan analisis distraktor pada soal TPA ditunjukkan pada Tabel 2.

TABEL 1

Hasil Perhitungan dan ANALISIS TINGKat KesuKaran SoAl TPA

\begin{tabular}{|c|c|c|c|c|c|}
\hline Soal & Jumlah Benar & Jumlah Salah & Total & Tingkat Kesukaran & Kategori Tingkat Kesukaran \\
\hline Tes Potensi Akademik 1 & 126 & 74 & 200 & 0.63 & Sedang \\
\hline Tes Potensi Akademik 2 & 79 & 127 & 206 & 0.38 & Sedang \\
\hline Tes Potensi Akademik 3 & 140 & 81 & 221 & 0.63 & Sedang \\
\hline Tes Potensi Akademik 4 & 134 & 93 & 227 & 0.59 & Sedang \\
\hline Tes Potensi Akademik 5 & 121 & 74 & 195 & 0.62 & Sedang \\
\hline Tes Potensi Akademik 6 & 198 & 10 & 208 & 0.95 & Mudah \\
\hline Tes Potensi Akademik 7 & 179 & 17 & 196 & 0.91 & Mudah \\
\hline Tes Potensi Akademik 8 & 49 & 152 & 201 & 0.24 & Sukar \\
\hline Tes Potensi Akademik 9 & 187 & 1 & 188 & 0.99 & Mudah \\
\hline Tes Potensi Akademik 10 & 203 & 16 & 219 & 0.93 & Mudah \\
\hline Tes Potensi Akademik 11 & 138 & 56 & 194 & 0.71 & Mudah \\
\hline Tes Potensi Akademik 12 & 76 & 118 & 194 & 0.39 & Sedang \\
\hline Tes Potensi Akademik 13 & 167 & 36 & 203 & 0.82 & Mudah \\
\hline Tes Potensi Akademik 14 & 208 & 2 & 210 & 0.99 & Mudah \\
\hline Tes Potensi Akademik 15 & 135 & 53 & 188 & 0.72 & Mudah \\
\hline Tes Potensi Akademik 16 & 89 & 112 & 201 & 0.44 & Sedang \\
\hline Tes Potensi Akademik 17 & 195 & 8 & 203 & 0.96 & Mudah \\
\hline Tes Potensi Akademik 18 & 91 & 106 & 197 & 0.46 & Sedang \\
\hline
\end{tabular}




\begin{tabular}{lccccc}
\hline Soal & Jumlah Benar & Jumlah Salah & Total & Tingkat Kesukaran & Kategori Tingkat Kesukaran \\
\hline Tes Potensi Akademik 19 & 57 & 141 & 198 & 0.29 & Sukar \\
\hline Tes Potensi Akademik 20 & 139 & 40 & 179 & 0.78 & Mudah \\
\hline Tes Potensi Akademik 21 & 69 & 151 & 220 & 0.31 & Sedang \\
\hline Tes Potensi Akademik 22 & 161 & 24 & 185 & 0.87 & Mudah \\
\hline Tes Potensi Akademik 23 & 70 & 133 & 203 & 0.34 & Sedang \\
\hline Tes Potensi Akademik 24 & 175 & 36 & 211 & 0.83 & Mudah \\
\hline Tes Potensi Akademik 25 & 148 & 68 & 216 & 0.69 & Sukar \\
\hline Tes Potensi Akademik 26 & 53 & 138 & 191 & 0.28 & Mudah \\
\hline Tes Potensi Akademik 27 & 157 & 62 & 219 & 0.72 & Mudah \\
\hline Tes Potensi Akademik 28 & 147 & 31 & 178 & 0.83 & Sedang \\
\hline Tes Potensi Akademik 29 & 111 & 93 & 204 & 0.54 & Mudah \\
\hline Tes Potensi Akademik 30 & 195 & 10 & 205 & 0.95 & Sedang \\
\hline Tes Potensi Akademik 31 & 117 & 59 & 176 & 0.66 & Sukar \\
\hline Tes Potensi Akademik 32 & 44 & 130 & 174 & 0.25 & Sedang \\
\hline Tes Potensi Akademik 33 & 130 & 71 & 201 & 0.65 & Sedang \\
\hline Tes Potensi Akademik 34 & 68 & 135 & 203 & 0.33 & Mudah \\
\hline Tes Potensi Akademik 35 & 135 & 46 & 181 & 0.75 & \\
\hline
\end{tabular}

TABEL 2

HASIL PERHITUNGAN DAN ANALISIS DISTRAKTOR SOAL TPA

\begin{tabular}{|c|c|c|c|c|c|c|}
\hline Soal & Jawaban A & Jawaban B & Jawaban C & Jawaban D & Jawaban E & Kategori Soal \\
\hline Tes Potensi Akademik 1 & $17.50 \%$ & $63.00 \%$ & $7.00 \%$ & $8.50 \%$ & $4.00 \%$ & Perlu Diperbaiki \\
\hline Tes Potensi Akademik 2 & $38.35 \%$ & $33.50 \%$ & $6.31 \%$ & $6.31 \%$ & $15.53 \%$ & Diterima \\
\hline Tes Potensi Akademik 3 & $19.00 \%$ & $63.35 \%$ & $11.31 \%$ & $2.26 \%$ & $4.07 \%$ & Perlu Diperbaiki \\
\hline Tes Potensi Akademik 4 & $4.41 \%$ & $7.05 \%$ & $12.33 \%$ & $17.18 \%$ & $59.03 \%$ & Perlu Diperbaiki \\
\hline Tes Potensi Akademik 5 & $10.77 \%$ & $3.08 \%$ & $16.41 \%$ & $7.69 \%$ & $62.05 \%$ & Perlu Diperbaiki \\
\hline Tes Potensi Akademik 6 & $95.19 \%$ & $0.48 \%$ & $1.44 \%$ & $1.92 \%$ & $0.96 \%$ & Perlu Diperbaiki \\
\hline Tes Potensi Akademik 7 & $91.33 \%$ & $1.53 \%$ & $3.06 \%$ & $1.02 \%$ & $3.06 \%$ & Perlu Diperbaiki \\
\hline Tes Potensi Akademik 8 & $19.40 \%$ & $24.38 \%$ & $28.36 \%$ & $22.39 \%$ & $5.47 \%$ & Diterima \\
\hline Tes Potensi Akademik 9 & $0.00 \%$ & $99.47 \%$ & $0.00 \%$ & $0.00 \%$ & $0.53 \%$ & Perlu Diperbaiki \\
\hline Tes Potensi Akademik 10 & $0.91 \%$ & $2.74 \%$ & $92.69 \%$ & $0.00 \%$ & $3.65 \%$ & Perlu Diperbaiki \\
\hline Tes Potensi Akademik 11 & $71.13 \%$ & $17.01 \%$ & $0.52 \%$ & $10.31 \%$ & $1.03 \%$ & Perlu Diperbaiki \\
\hline Tes Potensi Akademik 12 & $1.03 \%$ & $39.18 \%$ & $20.10 \%$ & $35.05 \%$ & $4.64 \%$ & Perlu Diperbaiki \\
\hline Tes Potensi Akademik 13 & $2.46 \%$ & $82.27 \%$ & $5.42 \%$ & $6.40 \%$ & $3.45 \%$ & Perlu Diperbaiki \\
\hline Tes Potensi Akademik 14 & $99.05 \%$ & $0.95 \%$ & $0.00 \%$ & $0.00 \%$ & $0.00 \%$ & Perlu Diperbaiki \\
\hline Tes Potensi Akademik 15 & $71.81 \%$ & $8.51 \%$ & $9.57 \%$ & $9.57 \%$ & $0.53 \%$ & Perlu Diperbaiki \\
\hline Tes Potensi Akademik 16 & $34.33 \%$ & $5.97 \%$ & $44.28 \%$ & $12.94 \%$ & $2.49 \%$ & Perlu Diperbaiki \\
\hline Tes Potensi Akademik 17 & $2.46 \%$ & $0.99 \%$ & $96.06 \%$ & $0.00 \%$ & $0.49 \%$ & Perlu Diperbaiki \\
\hline Tes Potensi Akademik 18 & $46.19 \%$ & $17.26 \%$ & $5.58 \%$ & $4.57 \%$ & $26.40 \%$ & Perlu Diperbaiki \\
\hline
\end{tabular}




\begin{tabular}{lllllll}
\hline \multicolumn{1}{c}{ Soal } & Jawaban A & Jawaban B & Jawaban C & Jawaban D & Jawaban E & Kategori Soal \\
\hline Tes Potensi Akademik 19 & $14.14 \%$ & $36.36 \%$ & $15.66 \%$ & $28.79 \%$ & $5.05 \%$ & Diterima \\
\hline Tes Potensi Akademik 20 & $77.65 \%$ & $2.23 \%$ & $4.47 \%$ & $1.12 \%$ & $14.53 \%$ & Perlu Diperbaiki \\
\hline Tes Potensi Akademik 21 & $15.00 \%$ & $20.00 \%$ & $18.18 \%$ & $15.45 \%$ & $31.36 \%$ & Diterima \\
\hline Tes Potensi Akademik 22 & $3.78 \%$ & $1.62 \%$ & $87.03 \%$ & $0.00 \%$ & $7.57 \%$ & Perlu Diperbaiki \\
\hline Tes Potensi Akademik 23 & $14.29 \%$ & $34.48 \%$ & $10.34 \%$ & $13.30 \%$ & $27.59 \%$ & Diterima \\
\hline Tes Potensi Akademik 24 & $82.94 \%$ & $13.27 \%$ & $0.95 \%$ & $2.37 \%$ & $0.47 \%$ & Perlu Diperbaiki \\
\hline Tes Potensi Akademik 25 & $8.33 \%$ & $11.57 \%$ & $68.52 \%$ & $3.70 \%$ & $7.87 \%$ & Perlu Diperbaiki \\
\hline Tes Potensi Akademik 26 & $27.75 \%$ & $16.23 \%$ & $24.08 \%$ & $14.14 \%$ & $17.80 \%$ & Diterima \\
\hline Tes Potensi Akademik 27 & $1.83 \%$ & $71.69 \%$ & $10.50 \%$ & $2.28 \%$ & $13.70 \%$ & Perlu Diperbaiki \\
\hline Tes Potensi Akademik 28 & $15.73 \%$ & $0.00 \%$ & $82.58 \%$ & $0.56 \%$ & $1.12 \%$ & Perlu Diperbaiki \\
\hline Tes Potensi Akademik 29 & $8.33 \%$ & $17.16 \%$ & $54.41 \%$ & $15.69 \%$ & $4.41 \%$ & Perlu Diperbaiki \\
\hline Tes Potensi Akademik 30 & $95.12 \%$ & $0.98 \%$ & $0.49 \%$ & $2.93 \%$ & $0.49 \%$ & Perlu Diperbaiki \\
\hline Tes Potensi Akademik 31 & $1.14 \%$ & $8.52 \%$ & $66.48 \%$ & $15.91 \%$ & $7.95 \%$ & Perlu Diperbaiki \\
\hline Tes Potensi Akademik 32 & $25.29 \%$ & $12.07 \%$ & $44.83 \%$ & $2.87 \%$ & $14.94 \%$ & Perlu Diperbaiki \\
\hline Tes Potensi Akademik 33 & $5.47 \%$ & $64.68 \%$ & $9.45 \%$ & $20.40 \%$ & $0.00 \%$ & Perlu Diperbaiki \\
\hline Tes Potensi Akademik 34 & $17.24 \%$ & $40.39 \%$ & $8.37 \%$ & $0.49 \%$ & $33.50 \%$ & Perlu Diperbaiki \\
\hline Tes Potensi Akademik 35 & $3.87 \%$ & $15.47 \%$ & $74.59 \%$ & $4.97 \%$ & $1.10 \%$ & Perlu Diperbaiki \\
\hline
\end{tabular}

Keterangan : warna hijau adalah jawaban benar.

Pada hasil perhitungan tingkat kesukaran, dari 893 data soal TPA, 125 soal terdapat dalam kategori sukar, 339 soal masuk kategori sedang dan 429 soal masuk pada kategori mudah yang ditunjukan pada Gambar 3.

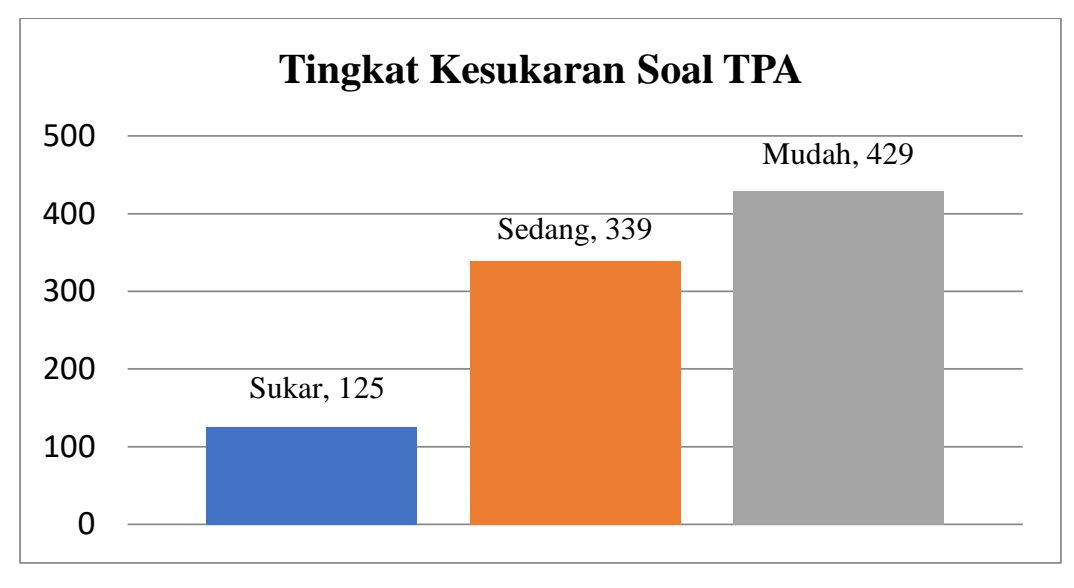

Gambar 3 Hasil perhitungan analisis tingkat kesukaran soal TPA

Pada hasil perhitungan analisis distraktor, dari 893 data soal TPA, 745 soal terdapat dalam kategori soal dengan distraktor atau jawaban pengecoh yang harus diperbaiki dan 148 soal dapat diterima dan digunakan yang ditunjukkan pada Gambar 4. 


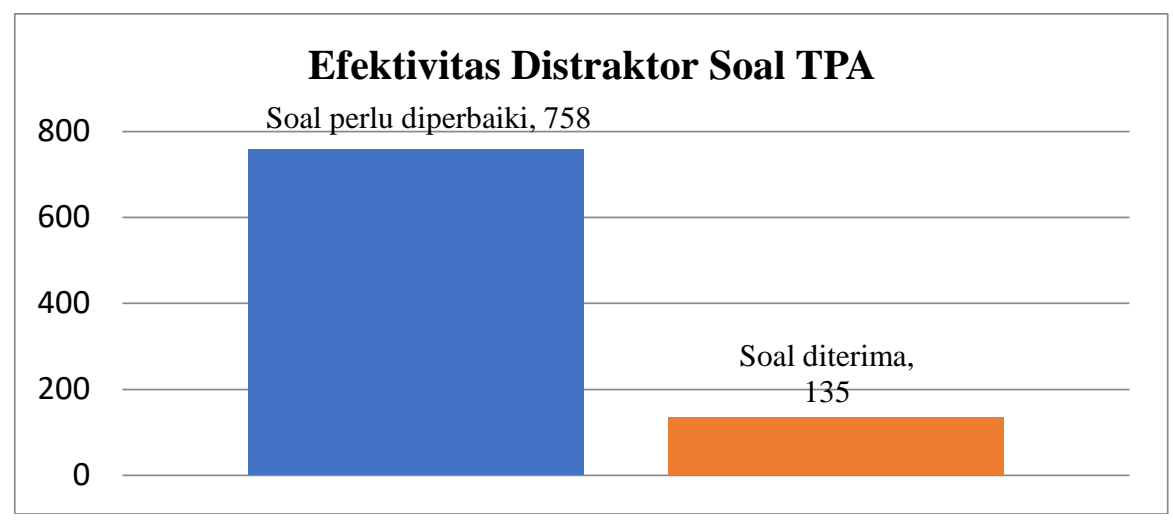

Gambar 4 Hasil perhitungan efektivitas distraktor soal TPA

Efektivitas distraktor pada soal TPA menunjukkan hasil yang kurang baik, ditunjukan dengan 758 butir soal perlu diperbaiki. Soal-soal tersebut memiliki alternatif pilihan jawaban lain atau distraktor yang diberikan dalam soal pilihan ganda dan yang bukan merupakan kunci jawaban kurang dengan nilai kurang dari $5 \%$. Contoh soal untuk menunjukkan efektivitas distraktor dalam paper ini adalah contoh soal ilustrasi, dikarenakan soal tidak dapat ditampilkan pada paper.

Contoh soal: Sinonim dari Heterogen adalah

a. Homogen

b. Unik

c. Khusus

d. Banyak

e. Plural

Jawaban e.

Jika yang mengikuti ujian 100 orang peserta dan yang memilih jawaban a adalah 4 orang (4\%), jawaban b adalah 31 orang (31\%), jawaban c adalah 2 orang (2\%) dan jawaban d adalah 8 orang (8\%) dan e adalah 55 orang (55\%), maka soal tersebut memiliki tingkat distraktor yang rendah. Distraktor yang rendah ditunjukkan dengan terdapat distraktor yang nilainya kurang dari $5 \%$, sehingga soal atau pilihan jawaban perlu diperbaiki.

\section{Analisis Soal Biologi}

Pada bagian ini dijelaskan mengenai hasil analisis kesukaran dan analisis distraktor pada soal TPA pada Universitas swasta di Bandung. Data yang digunakan untuk 123 data soal biologi manusia yang digunakan pada periode 2018 sampai dengan 2020 ujian saringan masuk universitas pada fakultas kedokteran, dengan rata-rata penggunaan dua blok soal yang berbeda setiap tahunnya. Perhitungan dan analisis tingkat kesukaran soal dan distraktor pada soal biologi dilakukan untuk keseluruhan data yang didapatkan, namun pada paper ini, ditampilkan sebanyak 35 data sampel atau data soal. Hasil perhitungan dan analisis tingkat kesukaran soal biologi manusia ditunjukkan pada Tabel 3 dan perhitungan analisis distraktor ditunjukkan pada Tabel 4.

TABEL 3

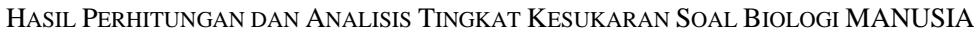

\begin{tabular}{clllll}
\hline Soal & Jumlah Benar & Jumlah Salah & Total & Tingkat Kesukaran & Kategori Tingkat Kesukaran \\
\hline Tes Biologi Manusia 1 & 338 & 171 & 509 & 0.66 & Sedang \\
\hline Tes Biologi Manusia 2 & 43 & 477 & 520 & 0.08 & Sukar \\
\hline Tes Biologi Manusia 3 & 207 & 346 & 553 & 0.37 & Sedang \\
\hline Tes Biologi Manusia 4 & 304 & 215 & 519 & 0.59 & Sedang \\
\hline Tes Biologi Manusia 5 & 206 & 273 & 479 & 0.43 & Sedang \\
\hline Tes Biologi Manusia 6 & 236 & 287 & 523 & 0.45 & Sedang \\
\hline Tes Biologi Manusia 7 & 263 & 261 & 524 & 0.50 & Sedang \\
\hline Tes Biologi Manusia 8 & 235 & 311 & 546 & 0.43 & Sedang \\
\hline
\end{tabular}




\begin{tabular}{|c|c|c|c|c|c|}
\hline Soal & Jumlah Benar & Jumlah Salah & Total & Tingkat Kesukaran & Kategori Tingkat Kesukaran \\
\hline Tes Biologi Manusia 9 & 373 & 190 & 563 & 0.66 & Sedang \\
\hline Tes Biologi Manusia 10 & 252 & 268 & 520 & 0.48 & Sedang \\
\hline Tes Biologi Manusia 11 & 397 & 173 & 570 & 0.70 & Sedang \\
\hline Tes Biologi Manusia 12 & 61 & 479 & 540 & 0.11 & Sukar \\
\hline Tes Biologi Manusia 13 & 77 & 473 & 550 & 0.14 & Sukar \\
\hline Tes Biologi Manusia 14 & 194 & 310 & 504 & 0.38 & Sedang \\
\hline Tes Biologi Manusia 15 & 235 & 276 & 511 & 0.46 & Sedang \\
\hline Tes Biologi Manusia 16 & 185 & 361 & 546 & 0.34 & Sedang \\
\hline Tes Biologi Manusia 17 & 195 & 310 & 505 & 0.39 & Sedang \\
\hline Tes Biologi Manusia 18 & 283 & 265 & 548 & 0.52 & Sedang \\
\hline Tes Biologi Manusia 19 & 256 & 284 & 540 & 0.47 & Sedang \\
\hline Tes Biologi Manusia 20 & 201 & 327 & 528 & 0.38 & Sedang \\
\hline Tes Biologi Manusia 21 & 49 & 459 & 508 & 0.10 & Sukar \\
\hline Tes Biologi Manusia 22 & 320 & 233 & 553 & 0.58 & Sedang \\
\hline Tes Biologi Manusia 23 & 173 & 324 & 497 & 0.35 & Sedang \\
\hline Tes Biologi Manusia 24 & 121 & 418 & 539 & 0.22 & Sukar \\
\hline Tes Biologi Manusia 25 & 410 & 143 & 553 & 0.74 & Mudah \\
\hline Tes Biologi Manusia 26 & 45 & 471 & 516 & 0.09 & Sukar \\
\hline Tes Biologi Manusia 27 & 222 & 292 & 514 & 0.43 & Sedang \\
\hline Tes Biologi Manusia 28 & 145 & 386 & 531 & 0.27 & Sukar \\
\hline Tes Biologi Manusia 29 & 289 & 265 & 554 & 0.52 & Sedang \\
\hline Tes Biologi Manusia 30 & 133 & 428 & 561 & 0.24 & Sukar \\
\hline Tes Biologi Manusia 31 & 148 & 391 & 539 & 0.27 & Sukar \\
\hline Tes Biologi Manusia 32 & 63 & 496 & 559 & 0.11 & Sukar \\
\hline Tes Biologi Manusia 33 & 160 & 337 & 497 & 0.32 & Sedang \\
\hline Tes Biologi Manusia 34 & 227 & 298 & 525 & 0.43 & Sedang \\
\hline Tes Biologi Manusia 35 & 323 & 187 & 510 & 0.63 & Sedang \\
\hline
\end{tabular}

TABEL 4

Hasil Perhitungan Dan ANALisis Distraktor SOAL BiOlogi MANUSIA

\begin{tabular}{cllllll}
\hline Soal & Jawaban A & Jawaban B & Jawaban C & Jawaban D & Jawaban E & Kategori Soal \\
\hline Tes Biologi Manusia 1 & $6.48 \%$ & $14.34 \%$ & $66.40 \%$ & $5.11 \%$ & $7.66 \%$ & Diterima \\
\hline Tes Biologi Manusia 2 & $8.27 \%$ & $52.69 \%$ & $4.04 \%$ & $10.38 \%$ & $24.62 \%$ & Perlu Diperbaiki \\
\hline Tes Biologi Manusia 3 & $49.55 \%$ & $37.43 \%$ & $5.06 \%$ & $6.15 \%$ & $1.81 \%$ & Perlu Diperbaiki \\
\hline Tes Biologi Manusia 4 & $32.95 \%$ & $1.35 \%$ & $58.57 \%$ & $5.39 \%$ & $1.73 \%$ & Perlu Diperbaiki \\
\hline Tes Biologi Manusia 5 & $17.33 \%$ & $14.82 \%$ & $43.01 \%$ & $17.33 \%$ & $7.52 \%$ & Diterima \\
\hline Tes Biologi Manusia 6 & $27.92 \%$ & $10.13 \%$ & $10.90 \%$ & $45.12 \%$ & $5.93 \%$ & Diterima \\
\hline Tes Biologi Manusia 7 & $13.74 \%$ & $28.63 \%$ & $6.30 \%$ & $1.15 \%$ & $50.19 \%$ & Perlu Diperbaiki \\
\hline Tes Biologi Manusia 8 & $9.71 \%$ & $10.81 \%$ & $12.64 \%$ & $43.04 \%$ & $23.81 \%$ & Diterima \\
\hline Tes Biologi Manusia 9 & $66.25 \%$ & $21.31 \%$ & $5.15 \%$ & $2.31 \%$ & $4.97 \%$ & Perlu Diperbaiki \\
\hline
\end{tabular}




\begin{tabular}{|c|c|c|c|c|c|c|}
\hline Soal & Jawaban A & Jawaban B & Jawaban C & Jawaban D & Jawaban E & Kategori Soal \\
\hline Tes Biologi Manusia 10 & $48.46 \%$ & $20.38 \%$ & $8.46 \%$ & $8.08 \%$ & $14.62 \%$ & Diterima \\
\hline Tes Biologi Manusia 11 & $14.21 \%$ & $69.65 \%$ & $1.40 \%$ & $13.16 \%$ & $1.58 \%$ & Perlu Diperbaiki \\
\hline Tes Biologi Manusia 12 & $7.41 \%$ & $11.30 \%$ & $45.74 \%$ & $30.19 \%$ & $5.37 \%$ & Diterima \\
\hline Tes Biologi Manusia 13 & $19.27 \%$ & $61.82 \%$ & $2.91 \%$ & $2.00 \%$ & $14.00 \%$ & Perlu Diperbaiki \\
\hline Tes Biologi Manusia 14 & $19.64 \%$ & $21.43 \%$ & $3.17 \%$ & $38.49 \%$ & $17.26 \%$ & Perlu Diperbaiki \\
\hline Tes Biologi Manusia 15 & $45.99 \%$ & $25.44 \%$ & $26.81 \%$ & $1.17 \%$ & $0.59 \%$ & Perlu Diperbaiki \\
\hline Tes Biologi Manusia 16 & $33.88 \%$ & $30.77 \%$ & $17.40 \%$ & $8.97 \%$ & $8.97 \%$ & Diterima \\
\hline Tes Biologi Manusia 17 & $9.11 \%$ & $38.61 \%$ & $26.73 \%$ & $20.20 \%$ & $5.35 \%$ & Diterima \\
\hline Tes Biologi Manusia 18 & $22.26 \%$ & $5.11 \%$ & $10.40 \%$ & $51.64 \%$ & $10.58 \%$ & Diterima \\
\hline Tes Biologi Manusia 19 & $10.93 \%$ & $14.26 \%$ & $47.41 \%$ & $13.33 \%$ & $14.07 \%$ & Diterima \\
\hline Tes Biologi Manusia 20 & $41.29 \%$ & $6.06 \%$ & $38.07 \%$ & $7.58 \%$ & $7.01 \%$ & Diterima \\
\hline Tes Biologi Manusia 21 & $6.30 \%$ & $10.83 \%$ & $9.45 \%$ & $69.49 \%$ & $3.94 \%$ & Perlu Diperbaiki \\
\hline Tes Biologi Manusia 22 & $57.87 \%$ & $15.73 \%$ & $9.04 \%$ & $4.34 \%$ & $13.02 \%$ & Perlu Diperbaiki \\
\hline Tes Biologi Manusia 23 & $25.96 \%$ & $33.80 \%$ & $1.21 \%$ & $4.23 \%$ & $34.81 \%$ & Perlu Diperbaiki \\
\hline Tes Biologi Manusia 24 & $4.45 \%$ & $22.45 \%$ & $19.11 \%$ & $18.00 \%$ & $35.99 \%$ & Perlu Diperbaiki \\
\hline Tes Biologi Manusia 25 & $8.32 \%$ & $9.76 \%$ & $5.79 \%$ & $1.99 \%$ & $74.14 \%$ & Perlu Diperbaiki \\
\hline Tes Biologi Manusia 26 & $54.65 \%$ & $17.64 \%$ & $15.31 \%$ & $3.68 \%$ & $8.72 \%$ & Perlu Diperbaiki \\
\hline Tes Biologi Manusia 27 & $8.17 \%$ & $15.18 \%$ & $23.93 \%$ & $43.19 \%$ & $9.53 \%$ & Diterima \\
\hline Tes Biologi Manusia 28 & $21.85 \%$ & $10.55 \%$ & $27.31 \%$ & $22.03 \%$ & $18.27 \%$ & Diterima \\
\hline Tes Biologi Manusia 29 & $51.99 \%$ & $9.93 \%$ & $10.65 \%$ & $25.81 \%$ & $1.62 \%$ & Perlu Diperbaiki \\
\hline Tes Biologi Manusia 30 & $27.45 \%$ & $23.71 \%$ & $18.36 \%$ & $18.18 \%$ & $12.30 \%$ & Diterima \\
\hline Tes Biologi Manusia 31 & $23.38 \%$ & $27.46 \%$ & $13.54 \%$ & $11.69 \%$ & $23.93 \%$ & Diterima \\
\hline Tes Biologi Manusia 32 & $21.82 \%$ & $57.78 \%$ & $11.27 \%$ & $6.62 \%$ & $2.50 \%$ & Perlu Diperbaiki \\
\hline Tes Biologi Manusia 33 & $12.68 \%$ & $32.19 \%$ & $1.61 \%$ & $5.84 \%$ & $47.69 \%$ & Perlu Diperbaiki \\
\hline Tes Biologi Manusia 34 & $43.24 \%$ & $20.57 \%$ & $11.24 \%$ & $10.10 \%$ & $14.86 \%$ & Diterima \\
\hline Tes Biologi Manusia 35 & $13.53 \%$ & $0.98 \%$ & $63.33 \%$ & $3.53 \%$ & $18.63 \%$ & Perlu Diperbaiki \\
\hline
\end{tabular}

Keterangan : warna hijau adalah jawaban benar.

Pada hasil perhitungan tingkat kesukaran soal biologi manusia, dari 123 data soal, 23 soal terdapat dalam kategori sukar, 86 soal masuk kategori sedang dan 14 soal masuk pada kategori mudah yang ditunjukan pada Gambar 5. Untuk soal sukar soal dapat dievaluasi kembali untuk menghasilkan soal yang sedang dan mudah.

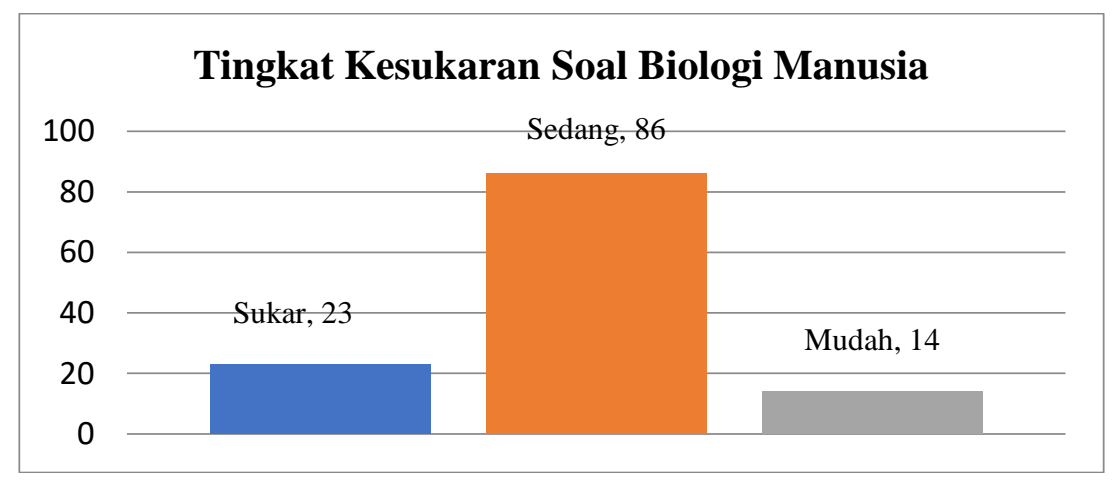

Gambar 5 Hasil perhitungan analisis tingkat kesukaran soal biologi manusia 
Pada hasil perhitungan analisis distraktor, dari 123 data soal biologi manusia, 78 soal terdapat dalam kategori soal harus diperbaiki dan 148 soal dapat diterima dan digunakan yang ditunjukkan pada Gambar 6. Untuk soal sukar soal dapat dievaluasi kembali untuk menghasilkan soal yang sedang dan mudah.

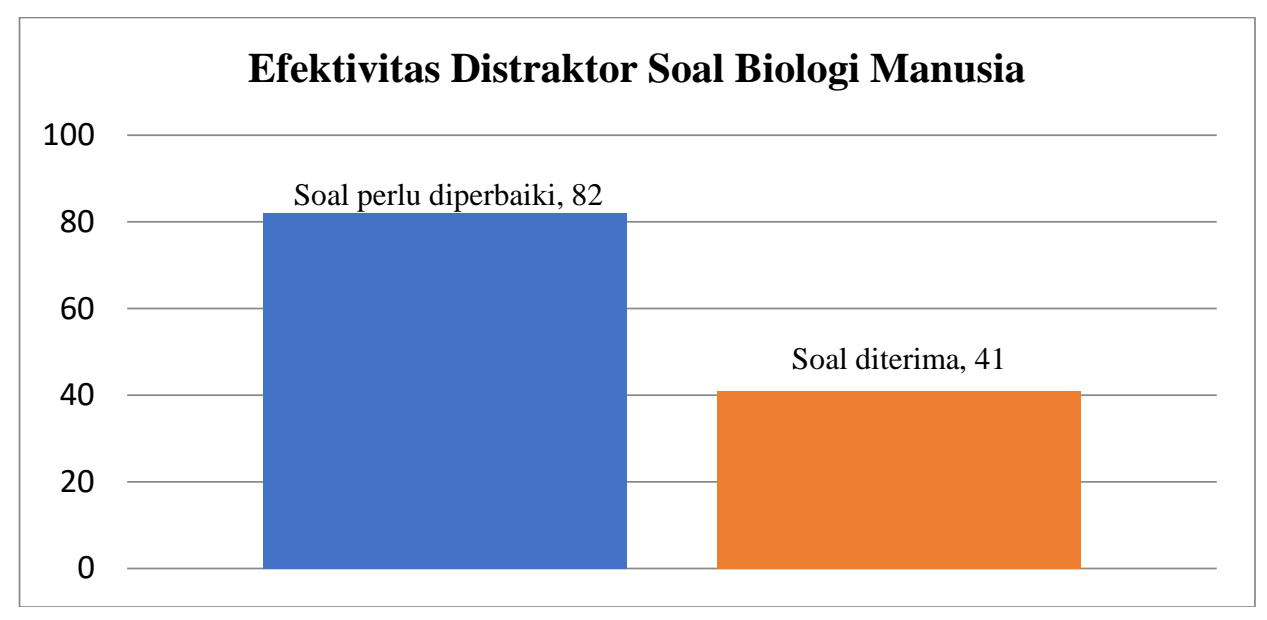

Gambar 6 Hasil perhitungan efektivitas distraktor soal biologi manusia

Efektivitas distraktor pada soal biologi manusia menunjukkan hasil yang kurang baik, ditunjukan dengan 82 butir soal perlu diperbaiki. Soal-soal tersebut memiliki alternatif pilihan jawaban lain atau distraktor yang diberikan dalam soal pilihan ganda dan yang bukan merupakan kunci jawaban kurang dengan nilai kurang dari $5 \%$. Contoh soal untuk menunjukkan efektivitas distraktor dalam paper ini adalah contoh soal ilustrasi, dikarenakan soal tidak dapat ditampilkan pada paper.

Contoh soal: Fungsi organ jantung pada tubuh manusia adalah ....

a. Memompa darah keseluruh tubuh

b. Sistem pernapasan

c. Menghancurkan racun dalam darah

d. Membantu pencernaan

e. Mengeluarkan zat sisa metabolisme

Jawaban benar adalah a.

Jika yang mengikuti ujian 100 orang peserta dan yang memilih jawaban a adalah 65 orang (65\%), jawaban b adalah 20 orang (20\%), jawaban c adalah 10 orang (10\%) dan jawaban d adalah 2 orang (2\%) dan e adalah 3 orang (3\%), maka soal tersebut memiliki tingkat distraktor yang rendah sehingga soal atau pilihan jawaban perlu diperbaiki. Distraktor yang rendah ditunjukkan dengan terdapat distraktor yang nilainya kurang dari $5 \%$, sehingga soal atau pilihan jawaban perlu diperbaiki.

Pada soal TPA, dari hasil perhitungan tingkat kesukaran, dari 893 soal yang diperhitungkan, terdapat 125 soal dalam kategori sukar dan 339 soal termasuk dalam kategori. Hasil perhitungan tingkat kesukaran dari 123 soal biologi manusia hasil perhitungan tingkat kesukaran menunjukkan 23 soal dalam kategori sukar dan 86 soal termasuk dalam kategori sedang. Soal pada kategori sukar untuk soal TPA dan biologi manusia, perlu dievaluasi kembali dan dilakukan perbaikan. Soal pada kategori sedang direkomendasikan untuk diperbaiki, agar soal dapat digunakan dengan lebih baik. Dalam perhitungan efektivitas distraktor untuk soal TPA, dari 893 soal terdapat 738 soal yang perlu diperbaiki dan untuk soal biologi manusia, dari 123 soal terdapat 82 soal yang perlu diperbaiki. Pada 738 soal TPA dan 82 soal biologi manusia tersebut memiliki pilihan jawaban yang kurang efektif berfungsi sebagai distraktor dan pilihan jawaban tersebut harus diperbaiki, agar distraktor dapat berfungsi secara efektif.

\section{SIMPULAN}

Penelitian yang dilakukan telah mengolah data soal pada sistem computer based test yang digunakan dalam pelaksanaan ujian saringan mahasiswa. Penggunaan sistem computer based test, membantu pihak universitas swasta di Bandung dalam pemilihan soal yang diberikan kepada peserta ujian, yang dilakukan berdasarkan blok soal. Pihak universitas memiliki banyak soal dan jawaban yang telah tersimpan dalam sistem menjadi bank soal. Pemanfaatan sistem computer based test, menjadikan soal yang diberikan pada setiap peserta berbeda dengan peserta lainnya dan dapat ujian dapat dilaksanakan 
secara online. Hasil jawaban peserta dapat dievaluasi dengan baik dan cepat, dikarenakan data soal dan jawaban telah disimpan dalam sistem computer based test. Hasil jawaban dari setiap peserta digunakan untuk mengetahui tingkat tingkat prestasi peserta ujian, yang dapat digunakan untuk merekomendasikan penerimaan peserta ujian sebagai mahasiswa pada universitas tersebut, namun data penerimaan peserta ujian menjadi mahasiswa tidak dapat dijabarkan dalam penelitian. Hasil jawaban dari setiap soal dianalisis untuk mengetahui tingkat kesukaran dan efektivitas distraktor. Soal yang telah dianalisis dengan menggunakan analisis tingkat kesukaran dan distraktor, yaitu soal TPA dan soal biologi manusia. Hasil analisis tingkat kesukaran dan distraktor, pada soal TPA dan biologi manusia, dapat disimpulkan bahwa soal TPA dan biologi manusia masih dapat digunakan, namun perlu diperbaiki dalam hal alternatif jawaban yang diberikan. Hal ini dikarenakan hasil perhitungan tingkat kesukaran soal yang menunjukkan soal dengan kategori mudah atau sedang, jumlahnya lebih besar dari kategori sukar. Hasil perhitungan untuk analisis efektivitas distraktor, menunjukkan kategori soal yang perlu diperbaiki memiliki jumlah yang lebih besar dibandingkan dengan yang masih dapat digunakan, dikarenak tingkat efektivitas distraktor masih rendah. Beberapa soal yang masuk pada kategori sukar dan memiliki nilai distraktor kurang dari 5\%, pada soal TPA dan biologi manusia, direkomendasikan untuk evaluasi dan diperbaiki.

\section{DAFTAR PUSTAKA}

[1] S. Mulianah and W. Hidayat, "Pengembangan Tes Berbasis Komputer," Kuriositas, p. 27, 2013.

[2] C. G. Parshall, J. A. Spray, J. Kalohn and T. Davey, Practical Considerations in Computer-Based Testing, Springer New York, 2012.

[3] D. Lestari, A. A. Musadad and S. Wahyuni, "Penggunaan Computer Based Test (Cbt) Sebagai Sarana Evaluasi Dan Pengaruhnya Terhadap Efektivitas Penilaian Pada Mata Pelajaran Sejarah Di Sma Negeri 1 Boyolali Tahun Ajaran 2015/2016,” Jurnal CANDI, p. $29,2019$.

[4] S. R. Utami Mizani Putri, “Aplikasi Computer Based Test (CBT) Sebagai Alternatif Evaluasi Hasil Pembelajaran Siswa,” JUSIFO - Jurnal Sistem Informasi, 2018.

[5] F. Maiziani, "Efektivitas Computer Based Testing Sebagai Sarana Tes Hasil Belajar,” JURNAL KIPRAH, p. $16,2016$.

[6] R. Rahayu and M. Djazari, “Analisis Kualitas Soal Pra Ujian Nasional Mata Pelajaran Ekonomi Akuntansi,” Jurnal Pendidikan Akuntansi Indonesia, 2016.

[7] I. S. Borualogo, S. Kusdiyati, S. and D. A. N. Sirodj, “Analisis Item Soal Uts Pedologi Semester Ganjil 2015-2016,” SHEMA, p. 46 , 2017.

[8] L. U. Fatimah and K. Alfath, “Analisis Kesukaran Soal, Daya Pembeda Dan Fungsi Distraktor,” Jurnal Komunikasi dan Pendidikan Islam, 2019.

[9] V. Kurniawan and T. Gantini, “Analisis Soal Ujian Saringan Masuk di Universitas X Dengan Pengunaan Metode Rumus Statistika," STRATEGI, 2020 .

[10] S. S. Dewi, R. M. Hariastuti and A. U. Utami, “Analisis Tingkat Kesukaran Dan Daya Pembeda Soal Olimpiade Matematika (Omi) Tingkat SMP Tahun 2018," TRANSFORMASI - Jurnal Pendidikan Matematika \& Matematika, p. 15, 2019.

[11] Supriyadi, EVALUASI PENDIDIKAN, NEM, 2021.

[12] S. M. Dr. H. Tobari, Evaluasi Soal-soal Penerimaan Pegawai Baru Dilengkapi dengan Hasil Penelitiannya, Yogyakarta: Deepublish, 2015.

[13] D. F. Setiawan, Prosedur Evaluasi dalam Pembelajaran, Yogyakarta: Deepublish, 2018.

[14] Yusrizal, Tanya Jawab Seputar Pengukuran, Penilaian, dan Evaluasi Pendidikan, Banda Aceh: Syiah Kuala University Press, 2015.

[15] Arikunto, Dasar-Dasar Evaluasi Pendidikan, Jakarta: Bumi Aksara, 2012. 